\title{
Emerald Insight
}

\section{Library Review}

Use of different information and communication technologies in Indian academic libraries:

Shabahat Husain Mohammad Nazim

\section{Article information:}

To cite this document:

Shabahat Husain Mohammad Nazim , (2015),"Use of different information and communication technologies in Indian academic libraries", Library Review, Vol. 64 Iss 1/2 pp. -

Permanent link to this document:

http://dx.doi.org/10.1108/LR-06-2014-0070

Downloaded on: 26 J anuary 2015, At: 20:40 (PT)

References: this document contains references to 0 other documents.

To copy this document: permissions@emeraldinsight.com

The fulltext of this document has been downloaded 21 times since 2015*

Access to this document was granted through an Emerald subscription provided by 483296 []

\section{For Authors}

If you would like to write for this, or any other Emerald publication, then please use our Emerald for Authors service information about how to choose which publication to write for and submission guidelines are available for all. Please visit www. emeraldinsight. com/authors for more information.

\section{About Emerald www.emeraldinsight.com}

Emerald is a global publisher linking research and practice to the benefit of society. The company manages a portfolio of more than 290 journals and over 2,350 books and book series volumes, as well as providing an extensive range of online products and additional customer resources and services.

Emerald is both COUNTER 4 and TRANSFER compliant. The organization is a partner of the Committee on Publication Ethics (COPE) and also works with Portico and the LOCKSS initiative for digital archive preservation.

$$
\text { *Related content and download information correct at time of download. }
$$




\section{Use of different Information and Communication Technologies in Indian Academic Libraries}

\section{Introduction}

Academic libraries are established to support teaching, learning, research activities and development of a culture of sharing and imparting knowledge to fulfil the mission and objectives of their parent institutions. Academic libraries also play a pivotal role in ensuring the success of higher degree of research. The important activities of academic libraries include collection development, references services, document delivery, access to organized collections held by the library and assist users in information search and retrieval (Cholin, 2005; Malhan, 2006). With the recent developments in Information and Communication Technology (ICT), especially the Internet and the World Wide Web, academic libraries are expected to initiate the next level of much desired services, i.e. just-in-time delivery of the most appropriate and high quality information at the place where it is desired using a state-of-the art ICT-based tools. The advantages offered by the ICT have led most academic libraries to provide ICT-based information services in order to meet the needs of its users (Bader, 2008; Woodward, 2009). The ICT approach has used in academic libraries attempts to deliver numerous applications such as local/wide area network applications, online information services, online journals and databases, library databases, online access catalogues, automated circulation facility, digital online archives (Ghuloum and Ahmed, 2011).

Recent advances in ICT have not only increased tremendously the ability to access, store and process information within the library but also have brought significant changes in the concept, organisation, functioning and management of library and information systems. In most of the academic libraries in the developed countries, Online Public Access Catalogues (OPACs) have almost replaced card catalogues, offering enhanced search capabilities for accessing the local collections; they often include the holdings of other area or regional libraries as well. Many libraries are also providing a web interface to their library and information system, often including direct links to electronic journals, books and Internet resources (Mohsenzadeh \& Isfandyari-Moghaddam, 2009). ICT can support the functions and services of academic libraries in two ways: by providing the means to acquire, organize, store, retrieve, and disseminate information (Sabashini, Rita, \& Vivek, 2012); and by connecting library users with librarians and library services through the use of web-based ICT tools to communicate with library users and share information and knowledge (Jain, 2007; Yuan, Zhao, Liao, \& Chi, 2013). The most common application of ICT-based tools in academic libraries include:

- Communication tools such as e-mail, instance messaging, telephones, teleconfering, Intranets and videoconfrencing, etc..

- Long-standing toos such as databases and institutional archives, etc..

- Socai media tools such as wikis, blogs, online communities, social networking sites.

Over the last two decades, academic libraries in India have witnessed the impact of ICT on the structure of services. The academic libraries in India are at various stages of development in the applications of ICT in their day to- day activities. Many academic libraries in India are already using computers and advanced telecommunication systems and many more are currently implementing such systems. Libraries in India have explored ICT for computerizing a wide range of administrative and technical 
processes, building databases, developing networks and providing innovative and intelligent information services. The widespread use of ICT in libraries has created a profound impact on library operations, information resources, information services, and staff competences and expectations of users (Peyala, 2011). Recently, some academic libraries have also stared using Intenet and Web 2.0 functionalities to communicate with users and to share knowledge within or outside libraries. Increasingly, libraries around the world are using blogs, wikis, Real Simple Syndication (RSS), social media and other Web applications for knowledge sharing purposes (Bejune, 2007; Chu Kai-Wah, 2009; Dickson \& Holley, 2010; Kim \& Abbas, 2010; Tripathi \& Kumar, 2010). These tools are being used to improve the exchange and flow of information in libraries (Nelson, 2008) and meeting information needs by being useful for knowledge sharing between librarians and library users and to communicate with library users (Mavodza and Ngulube (2011). However, there is uncertainty about whether to what extent these ICT tools are being used in Indian academic libraries. Accordingly, the present study is an attemt to examine the use of different ICT-based tools in Indian academic libraries at various levels.

\section{Review of Literature}

ICT-based tools and applications are widely used in libraries to facilitate networking and resource sharing, eliminate duplication of efforts, improve the speed of operations, increase access to information resources and improve the quality of information services (Peyala, 2011). Use of ICT applications can also assist libraries in creating, storing, transferring and using tacit and explicit knowledge. Libraries can use numerous ICT-based tools including, integrated library management systems, competency databases, decision support systems, online retrieval and search systems, expert networks, e-mail, groupware, teleconferencing, intranet, WWW, document management systems, video conferencing, meta data and data mining (Okumus, 2012; Peyala, 2011; Rah, Gul, \& Wani, 2010; Shanhong, 2000).

Mohsenzadeh and Isfandyari-Moghaddam (2009) performed a study to define the status of the application of ICT in academic libraries in Kerman, Iran. Results showed that the level of application of ICT in Kerman academic libraries was acceptable, but efforts should be made to improve their status to match with the ever-increasing demand for better library services at universities. The most important problem and serious difficulty was lack of educated librarians, which requires suitable investment and planning. Ramzan and Singh (2009) investigated the levels of ICT application in academic libraries across Pakistan and found a lack of ICT infrastructure, especially the absence of computers, e-mail and internet. It was revealed that the respondent libraries needed to be fully automated using standard library software. However, access to online resources was found to be extensive and comprehensive.

Parirokh, Daneshgar \& Fattahi (2008), on the basis of a survey in USA, report that how sharing of knowledge through the use of ICT among librarians can improve organizational learning in academic libraries. The findings of the study show that almost all libraries use email and library Website as part of their communication system. The Intranet and telephone lines have also been used by most libraries. However, the traditional face-to-face communication method is also widely used. Virtual reference desk and user mailing lists, which are relatively new artifacts, have been used by about half of the participating libraries, probably waiting for a wider acceptance in future.

Gandhi (2004) describes the value of capturing tacit knowledge of reference librarians and explained the early efforts of reference librarians in capturing tacit knowledge through old information tools like cardfiles of frequently-asked questions. However, with the recent developments in ICT, these practices have 
been replaced by the use of Common Knowledge Databases (CKDB) (Jantz, 2001), web-based ReadyReference Databases (Stover, 2004) and Knowledge Bank (Branin, 2003). Both Jantz (2001) and Stover (RRD) (2004) described the introduction of a new tool that has been developed by a team of reference librarians. Jantz (2001) examined how reference librarians could become more effective with the use of ICT tools and shared his experience of the development and use of CKDB within the New Brunswick Campus Libraries of Rutgers University. Stover (2004) shared his experience of the development of a Web-based RRD for reference services at San Diego State University to capture and reuse the tacit and informal knowledge of reference librarians.

Some scholars suggest for creating and maintaining digital library or institutional repository as a tool for storaging, retrieving and sharing all the intellectual assets of the university in a range of formats, including those that are unpublished, unstructured and unique (Ayanbode, 2011; Branin, 2003; Kao and Wu, 2012; Rah, Gul and Wani, 2010; Robertson and Sullivan' 2000). This is because technology in digital libraries is an enabler in the modern information supply chain (Abell, 2000; Jain, 2007; Singh, 2007) and librarians must be skilled at the technical aspects of the job.

Based on the review of literature, Bem \& Coelho (2013) identified the trends and applications of modern ICT-based tools in libraries and found that libraries have often developed ICT-based applications (especially regarding the sharing of knowledge through Web 2.0 features). Modern ICT-based tools, such as blogs, wikis, shared classification systems (tagging), social networks, etc. are mostly used in libraries. $\mathrm{Xu}$, Ouyang and $\mathrm{Chu}$ (2009) investigated the use of Web 2.0 functionalities in academic libraries by visiting 81 academic library websites in the New York. The findings reveal that $42 \%$ of libraries adopted one or more Web 2.0 functionalities such as blogs while implementation of these in individual libraries varies greatly. They have also proposed a conceptual model of Academic Library 2.0 in their report. Redden (2010) explored the potential utilization of social bookmarking web sites by academic libraries. He argues that these web sites, which allow users and organizations to create accounts for bookmarking online content, to facilitate academic libraries in collaboration and networking, organization and sharing of electronic resources and teaching information literacy. Mphidi and Snyman (2004) focused on the utilization of intranet in academic libraries, especially in South Africa. The purpose of the study was to report the extent to which academic libraries in South Africa are utilizing the intranet. The study found that a strong awareness is existed of the importance of ICT as knowledge sharing tool. Though the content and use of the intranet was vary from library to library, it was observed from the findings that academic libraries did not utilize the full potential of the intranet. Based on the questionnaire survey of 20 library directors working in the academic libraries of eastern USA, Kim and Abbas (2010) invetigated the use of Web 2.0 tools in academic libraries. Based on randomly selected 230 academic library Web sites and 184 users, they investigated the adoption of Web 2.0/ Library 2.0 functionalities by academic libraries and their users. It was found that RSS and blogs were widely adopted by academic libraries while the bookmark function was rarely used by users.

Studies on the use of ICT in India indicate that computerization of library systems and services in India started in the mid 1970s. However, this trend has accelerated during last two decades especially in institutions of higher education due to the increased number of students, greater demand for the use of library material within and outside the library, increasing in the amount of materials being published and the development of new and cheaper computers. Over the last three decades libraries in India have witnessed the impact of ICT on the structure and functioning of services. Many libraries in India are already using ICT and advanced communication systems and many more are currently in the process of 
implementing such systems. Information Library Network (INFLIBNET) Centre, an inter-university centre of University Grants Commission, has been supporting, funding and providing necessary assistance to university libraries for automation and networking for last several years.

For the first time, Kumar (1987) surveyed the status of ICT applications in university libraries of India and found that Delhi University Library conducted stocktaking using computer in 1970, Andhra University Library produced the list of new additions in 1970s, SNDT University Library obtained computer in 1985 and Marathawara University Library acquired minicomputer for library operations in 1985. Raman and Rao (2003) have made a useful study on the use of ICT in central university libraries in India. The survey has provided a useful summary of current state of the art of using ICT in libraries in India. The survey confirmed that ICT has deeply embedded itself in the management of information in university libraries. It has become a powerful tool in the handling of routine library operations and services. The analysis has shown that the use of ICT in libraries is increasing steadily and significantly and university libraries had developed the infrastructure for the use of ICT for the house keeping operations and online services to the users. Moreover, the study revealed an awareness of current developments concerned with end users. Vyas (2003) conducted a survey of 12 university libraries of Rajasthan and Indian Institutes of Technology and found that most of the libraries have implemented ICT to their in-house activities and services, to automate and digitize resources and to share resources at local and national level.

Haneefa (2007) carried out a study to examine the application of ICT in special libraries in Kerala, India. The results indicate that library automation in special libraries in Kerala was largely commenced during 1990-2000. CDS/ISIS was used more in libraries than any other software. The library catalogue was found to be the most popular area for automation. Most of the libraries were hampered by lack of funds, lack of infrastructure, and lack of skilled professionals to embark on automation of all library management activities and application of ICT. Raza and Nath (2007) measured the use of ICT in the university libraries of Punjab, Himachal Pradesh and Chandigarh (India) with an ulterior objective to establish some co-relation between quality in libraries and use of ICT. They have also highlighted the access of networks, information services and barriers in ICT applications. Ultimately, it was emphasized that although quality depends on merging print culture with digital culture, the results confirm that print culture is still dominating in university libraries of this region. Central library of Jammu is the first university library in India which has implemented the modern ICT including RFID technology (Malhan, 2006). Tiwari and Sahoo (2013) conducted a survey of university libraries of Rajasthan to explore the availability of ICT infrastructure, applications of ICT in housekeeping operations and user's services, requirements of training and problems encountered during the implementation ICT. The findings revealed that ICT activities are under developing stage in the university libraries of Rajasthan. The lack of basic management and proper planning and frequently change in ICT are the basic hurdles for successful implementation and development of ICT.

Madhusudhan and Nagabhushanam (2012) examined how some of the university libraries in India provide web access to their collections and user support for that access and the problems faced by users in accessing Web-based library services. Findings show that a few surveyed university libraries offer innovative Web-based library services in different sections and many are yet to exploit full potential of the Web forms, and lagging behind in effective use of library website. Preedip and Kumar (2011) in their study found that Web information services are not widespread and have yet to take off widely in academic Libraries in India; the diffusion rate of Web 2.0 information services is relatively low. Tyagi 
(2012) observed that a large number of respondents had knowledge about Web 2.0 tools and were more inclined to adopt the Web 2.0 technologies in their personal lives. However, libraries are lagging behind in using the social networking technologies. Bhardwaj (2014) investigated how library and information science professionals working in higher education institutions in India integrate social networking sites (SNS) into their routine work. The findings revealed that information professionals use SNS to socialize, keep themselves up-to-date, find jobs, and acquire information about conferences and seminars in their respective fields.

\section{Need and Objectives of study}

Academic libraries contribute to educational and research activities in many ways through exploiting ICT and electronic information resources, such as e-books; online journals/databases and Web-based information services. Over the years several ICT-based applications and services have evolved which are being used in libraries to support the process of knowledge capturing, storing and sharing. Modern ICT-based tools such as Internet, Web 2.0, and Social media are increasingly used in libraries as information sharing tools. They are also used in libraries to connect library users with libraries and make relationship between librarians and library users. Many studies have been done in developed countries to investigate the impact of these ICT-based tools on libraries and library services, no research has been conducted on the use of different types of ICT-based tools in academic libraries in India. According to Haneefa (2007), libraries procure expensive ICT equipments but they may not be optimally used. This is the main concern of librraies around the world. There may be several reasons for state of affairs, like lack of qualified and trained library staff. In view of these fact, an attempt has been made to study the use of ICT-based tools and services in academic libraries in India.

The purpose of the study was to examine the use of different ICT-based tools in Indian academic libraries. However, the more specific objectives of the study are as follows:

- To explore the implementation of ICT in the housekeeping operations and services

- To identify the use of different ICT-based tools for knowledge sharing

- To examine the librarians' perceived challenges of ICT application.

\section{Methodology}

We conducted a survey of academic libraries in India to address these objectives. A survey method is defined by Powell and Connaway (2004) as a research strategy that encompasses any measurement procedures that involve asking questions from the respondents concerning the current status of subject of the study. Survey method helps to collect primary data for describing a population too large to observe directly. Academic institutions and their libraries in India are too numerous to consider as sample for any research. Therefore, only libraries of the central universities were included in this study, keeping in mind that these are funded by the central government of India and might have advanced library infrastructure and facilities. Of the total 42 central universities in India, 12 were established recently in 2009 and are in the process of developing infrastructure, academic programmes and libraries. Therefore, 30 central universities, established before 2009, were selected on the basis of collections, infrastructure and services at various locations within India. Purposive sampling method was used to explore the use 
of different ICT-based tools in academic libraries in India. The university librarians of these universities were selected as respondents. However, in the absence of the university librarian, an officer up to the rank of assistant librarian could participate in the survey.

A questionnaire that included closed ended questions (see the appendix for the questions) was used as the data collection instrument. Questions in the questionnaire were grouped into five sections. The first section aimed at gaining basic information such as name of the library, year of establishment, total collection, number of sanctioned posts and number of staff currently working, etc. The second section explored the implementation of ICT in various library operations and services. The third section was to examine the use of ICT-based interactive tools used for sharing of knowledge in the respondents' library. The fourth section was to know the requirements of training for library staff in handling ICTbased systems. The fifth section was to examine the barriers related to the use of ICT-based applications.

A total of thirty (30) questionnaires were delivered by postal mail. Two months after sending the questionnaires, Twelve (12) completed questionnaires were received. After that, first follow-up letter as reminder was sent to the librarians who were yet to return the questionnaires. Then three (3) more dully filled questionnaires were received. Second follow-up letter as reminder was sent again to the librarians who have not returned the questionnaires yet. But there was no response at all. The number of returned questionnaires was 15 , a response rate of $50 \%$. The libraries that participated in the study were from nine different states of the country: four from Uttar Pradesh, four from Delhi, one each from Andhra Pradesh, West Bengal, Kerala, Chhattisgarh, Manipur, Mizoram and Meghalaya. These libraries are spread around a $4000 \mathrm{~km}$ area and serve an extended community of users. They are very different libraries in terms of staff and users. As it was not a large amount of data, data analysis was done by simple frequency count and is presented in tables. The details of libraries participating in the study are shown in Table 1. Column A denotes the serial number. Column B identifies the name of the University. Column $\mathrm{C}$ provides the year each university and its library was established. Column D provides an indication of the relative size of each library based on total collection. Column $\mathrm{E}$ indicates total number of sanctioned posts and number of staff currently working in the participating libraries.

This research is limited as regards to the generalization of the findings. Although the intention of researchers was to cover different types of academic libraries in India, the investigation succeeded mainly in obtaining responses from the librarians of the central universities due time and financial constraints. Thus, the result of this study is not representation of all types of academic libraries and, therefore, might not be generalized to other libraries. Moreover, despite being distributed questionnaires to 30 librarians, the sample size is still relatively small. Thus, both the quantity and variety of responses may be too small in some instances for meaningful comparisons and conclusions.

\section{Results}

\section{Library Collection}

Library collection forms a sound foundation for efficient services. The details of the total collection of the responded libraries are presented in Table 1. As may be observed from Table 1, Delhi University Library System (DULS) has the largest collection of more than 1.47 million books including back volumes of periodicals, followed by Aligargh Muslim University (AMU) with about 1.18 million and Banaras Hindu University (BHU) with over 1.06 million. On the other hand, Babasaheb Bhimrao 
Ambedkar University (BBAU) and Mizoram University (MU) have the smallest collection of books and other reading materials ( 0.01 million $\& 0.08$ million respectively).

\section{Library Staff}

Human resource plays a prominent role for the successful management of any library. The details of human resources available in academic libraries are presented in Table 1 . The table, as per the study, demonstrates that there are 1122 sanctioned posts in 15 academic libraries (15 central university libraries). It is surprising to note that out of 1122 sanctioned posts, 422 posts were lying vacant and 700 staff members were currently working in these libraries. Out of 15 libraries, DULS has the largest number of sanctioned post as well as staff presently working (416 sanctioned, 126 working), followed by BHU (159 sanctioned, 122 working) and AMU (121 sanctioned, 100 working).

\section{Computerized library operations and services}

Mere availability of ICT or software in a library is not enough, unless these technologies or systems are put to use for solving problems of work environment. The respondents were asked to indicate the functions and services of their library, which are based on ICT applications. In order to obtain a benchmark on the progress of implementing Integrated Library Management System for housekeeping operations, the survey offered a list of functions and asked the respondents to mark the computerized operations in their libraries. Although, the question asked for a list of operations currently in use, responses appear to include planned as well as current operations. As Table 2 shows, automation of library catalogues has implemented in almost all libraries, followed by circulation systems (85\%), serial control (85\%) and acquisition \& budget (75\%). Other applications were management information (45\%) and RFID (20\%). Three libraries indicated that RFID systems for theft control in their libraries are under process. The data analysis reveals that the majority of libraries surveyed have various operations automated.

Further, respondents were asked to indicate the use of ICT-based services provided by the libraries to their users. As shown in Table 3, 80 per cent libraries provide access to in-house developed library databases, 75 per cent provide access to electronic resources (e-books, e- journals, e-databases, etc.) and 55 per cent provide Web-based reference or other information services. However, as shown in Table 3, other technology-based services such as online tutorials (40\%), subject gateways/Web portals $(35 \%)$, automatic (electronic) mailing alert system (10\%) and FAQ database (15\%) are among the least used ICT-based methods for sharing knowledge between librarians and users. It seems that participating libraries have not effectively used ICT for this activity.

\section{Use of ICT-based tools for communication and knowledge sharing in academic libraries}

Various ICT-based tools that are currently used by the librarians for communication with their staff, library users or other libraries are shown in Table 4. These technologies correspond to the communication channels, repositories, databases and new generation of interactive social media that enable a pair of roles collaborate in performing their collaborative tasks. As shown in Table 4, almost all libraries use email and telephone calls as part of their communication system. However, videoconferencing, which is an effective interactive communication method, has been used by a few of the participating libraries (15\%). The Intranet $(80 \%)$ and Institutional Repositories/Digital libraries (65\%) have also been used by most libraries. However, Resource Discovery Tools, which is relatively new technique for searching massive metadata for easier navigation and retrieval, is used by a few libraries $(20 \%)$. 
With the emergence of Web 2.0 and social media tools, the relationship between the library and their users has dramatically changed. These tools may be used by libraries for personalizing outreach services. The application of these tecnologies may help libraries offer their resources and services to the users in a proactive manner. With the use of these tools, users can also participate in activities that were once the sole purview of the library, such as cataloging via folksonomy, or providing comments on books via blogging (Casey \& Savastinuk, 2006). Use of blogs, Wikis, RSS feeds, social networking and social bookmarking in academic libraries in India seems uncommon, as indiacted by the respondents (seeTable 4).

\section{Availability of trained staff for handling ICT-based systems and services in libraries}

As examined in an earliers study by Nazim and Mukherjee (2013), ICT is perceived as the most required competencies among LIS professionals to involve in KM practice. Therefore, respondents in the present study were asked to indicate whether staff in their libraries adequately trained or require training in various ICT-based applications. The results are presented in Table 5. It may be observed from the table that all the respondents indicated that trained staff is not available in their libraries for handling ICTbased based systems and services and they need training. Areas where respondents indicated the requirement of training were computer programming $(80 \%)$, Website or portal development $(75 \%)$, hardware maintenance $(65 \%)$, metadata or e-resource management and content management $(50 \%)$. Database creation and management is the only area where majority of respondents indicated that the trained staff is available. However, 35 per cent respondents indicated that training is needed in this area too.

\section{Librarians' perceived challenges of ICT-based based systems and services}

Table 6 indicates the ranked order of the number of constraints faced by librarians in the use of ICTbased based systems and services. The highly ranked constraints were lack of trained staff in ICT, low level of ICT skills among library users, unawareness of potential benefits of ICT and inadequate ICT infrastructure. Similar constraints have identified in earlier studies by Raman \& Rao (2003) and Cholin (2005). Inadequate funds for ICT infrastructure development was identified as the major problem by these researchers. However, in the present study it was ranked at 5 by the respondents. This may be due to over emphasis on the development of ICT infrastructure by universities during last ten years. The least ranked constraints were resistance of library staff to use ICT and lack of updated ICT policy and strategy.

\section{Summary of findings}

- Majority of the libraries of the central universities in India have implemented ICT in housekeeping operations such as library catalogues, circulation systems, serial control, acquisition \& budget. However, libraries are lacking ICT implementation in the areas of management information systems and RFID.

- ICT-based information services such as access to in-house developed library databases, access to electronic resources (e-books, e- journals, e-databases, etc.) and Web-based reference services are offered by majority of the libraries of the central universities. However, other ICT-based services such as online tutorials, subject gateways/Web portals, automatic (electronic) mailing 
alert system and FAQ database are among the least used methods for delivery of information services to the users.

- Among the communication tools, email, telephone calls and Intranet are being used as a part of their communication system by most of the libraries. However, videoconferencing, which is an effective communication system, has little use in the libraries.

- Majority of the academic libraries in India have either created institutional repository or maintain digital library for providing online access to variety of information resources. However, Resource Discovery Tools, which are used for searching and locating library's local and remote content at single search interface, has not gained momentum in Indian academic libraries.

- The use of Socai media tools such as blogs,Wikis, RSS feeds, social neworking and social bookmarking in academic libraries in India is also uncommon as emerged from the results of the present study.

- Almost all the respondents indiacted the requirements of trained staff in various area of ICT applications, including computer programming, Website or portal development, hardware maintenance, metadata or e-resource management and content management.

- Lack of trained staff in ICT, low level of ICT skills among library users, unawareness of potential benefits of ICT and inadequate ICT infrastructure are observed as the major constraints in the applications of ICT in academic libraries in India.

\section{Discussion \& Conclusion}

The findings of the present study indicate that academic libraries in India have mostly been involved in applying ICT-based solutions for the management of various library functions and services, including computerization of library catalogues, circulation systems, serial control, acquisition and budget, access to in-house developed library databases, access to electronic resources (e-books, e- journals, edatabases, etc.) and Web-based reference services. Generally, most of the academic libraries in India are using ICT-based applications for organizing and retrieving information. As the need for the delivery of information services within or outside the campus emerged, their involvement increased towards the development of Intranets and institutional archives or digital libraries. Additionally, librarians are using traditional tool of knowledge transfer and sharing such as email and teleconferencing. The reason for the extensive use of telephone call may be due the fact that these technologies have been available for decades and librarians are familiar with them. Use of these tools is often the employees' first and instinctive reaction when looking of help or advice. However, use of videoconferencing, which is an effective interactive communication method, was not much in practice, probably due to lack the sufficient funds to easily afford it. Modern ICT-based tools of knowledge creation, identification and sharing like Web discovery tools, blogs, Wikis, RSS feeds, social neworking and social bookmarking are being used by libraies in developed countries very commonly (Tripathi \& Kumar (2010). It may be observed from the review of literaure that LIS professionals in India are aware of Web 2,0 and Social Networking Sites (SNS) and active on SNS to socialize and keep themselves up-to-date, find jobs, and acquire information about conferences and seminars in their respective fields (Bhardwaj, 2014; Tyagi, 2012), but their involvement at institutional level for promoting library services and communication with users seems uncommon, as emerged for the findings of present study.

Although there is an indication of the application of various ICT-based communication and knowledge sharing tools (such as intranets and institutional repositories, content management, etc.), academic libraries in India are still in the early stage of the implementation of these technologies. Some of the 
roles of librarians in ICT environment include: understanding and articulating the nature of social media, creating Websites or Blogs, establishing friendly user interface over the network and content management. Most of the academic libraries in India are struggling to incorporate modern ICT-based tools, resources and services due to inadequate skill and expertise of library staff. It urges the authorities to recruit multi-skilled library staff familiar with the implementation of ICT-based tools, resources and services. As the development of ICT infrastructure depends on the availability of funds, lack of ICT infrastructure and lack of funds were identified as the major challenges of implementing ICT-based resources and services in an earlier study of academic libraries of Kerala (India) by Haneefa (2007). But during the last ten years libraries, particularly central universities libraries in India, received sufficient funds as well as assistance towards the development of ICT infrastructure. That is why, although lack of funds and lack of ICT infrastructure were still perceived as the barriers to the ICT use by the majority of the respondents, but they have ranked them at four and five place respectively in the order of priority (see table 6).

It may be concluded that the level of the application of ICT in Indian academic libraries is acceptable but they should improve their status to match the ever increasing demand for better library \& information services by utilizing their best potential of knowledge resources. Academic libraries should renovate existing library environment and develop knowledge and skills among their staff in the fields of computer programming, Website or portal development, hardware maintenance and metadata or eresource management for handling ICT-based information systems and providing quality information services to their respected user community. They are also needed to develop skills of searching and navigating the web, creating social network space, teaching, and providing quality online library services.

The posts which are lying vacant should be filled on an urgent basis. Librarians must recruit adequately trained staff to work with the modern ICT-based information systems. It is essential for academic libraries to initiate training programmes in collaboration with computer centres of the university, department of studies of library and information science and library associations.

Present research is significant because it shed light on the current level of adoption and use of modern ICT-based tools in library functions and services in the select university libraries. Thus, the findings of the study would help practicing librarians, policy makers, management and the University Grants Commission of India to promote the use of different ICT-based information systems in academic libraries and to design courses of ICT and to introduce training programmes for working staff. This research has also some limitations. Since it surveyed only fifteen university libraries, the sample may not accurately represent the whole population. For future research, a broad study should include more university libraries as well as expanding the study to other types of libraries in order to gain a broader perspective on the implementation of ICT. 


\section{References}

Abell, A. (2000), "Skills for knowledge environments", Information Management Journal, Vol. 34 No.3, pp.10-12.

Ayanbode, O. (2011),"Library digitisation: a strategy to bridge information and knowledge divides", European Journal of Scientific Research, Vol.56, No.2, pp.212-218.

Badar, A. (2008). Academic libraries. $2^{\text {nd }}$ ed. Cairo: House Strange Printing and Publishing.

Bejune, M. (2007), "Wikis in libraries", Information Technology in Libraries, Vol. 26 (September 2007), pp. 26-38.

Bem, R. M. D., \& Coelho, C. C. S. R. (2013), “Applications of knowledge management in the area of librarianship and information science: A systematic review", Brazilian Journal of Information Science, Vol. 7 No. 1 pp. 67-93.

Bhardwaj, R. K. (2014), "Use of Social Networking Sites by LIS Professionals in Higher Education Institutions in India: A Study”, The Reference Librarian, Vol. 55 No. 1, pp. 74-88.

Branin, J. J. (2003), "Knowledge management in academic libraries: building the knowledge bank at the Ohio State University", Journal of Librarv Administration, Vol. 39 No. 4, pp. 41-56.

Casey, M., \& Savastinuk, L. (2006), "Library 2.0: Service for the Next Generation Library", Library Journal, Vol. 131, pp. 40-42.

Cholin, V. S. (2005), "Study of the application of information technology for effective access to resources in Indian university libraries", The International Information \& Librarv Review, Vol. 37, pp.189-197.

Chu Kai-Wah, S. (2009), "Using Wikis in academic libraries", Journal of Academic Librarianship, Vol. 35, pp. 170-176.

Dalkir, K. (2005), Knowledge management in theory and practice, Boston: Elsevier.

Dickson, A., \& Holley, Robert P. (2010). "Social networking in academic libraries: the possibilities and concerns", New Librarv World, Vol. 111 No. 11/12, pp. 468-479.

Gandhi, S. (2004), "Knowledge management and reference service", The Journal of Academic Librarianship, Vol. 30 No. 5, pp. 368-381.

Ghuloum, H., \& Ahmed, V. (2011), “'The Implementation of New ICT Services in Kuwaiti Academic Libraries", The Built and Human Environment Review, Vol. 4 No. 1, pp. 74-86.

Haneefa, M. (2007), "Application of information and communication technologies in special libraries in Kerala (India)”, Librarv Review, Vol. 56 No. 7, pp. 603-20.

Isaac, A. M. (2008), “Transformation of India into a knowledge society", Paper presented at PICMET Conference on Technologv Management for a Sustainable Economv, July 27-31, 2008, cape Town, South Africa, available at:

http://www.knowledgecommission.gov.in/downloads/news/news314.pdf (accessed on 29 July 2014).

Jain, P. (2007), “An empirical study of knowledge management in academic libraries in East and Southern Africa", Librarv Review, Vol. 56 No. 5, pp. 377-392.

Jantz, R. (2001), "Knowledge management in academic libraries: special tools and processes to support information professionals", Reference Services Review, Vol. 29 No. 1, pp. 33-39. 
Kao, S.C., \& Wu, C. H. (2012), “A personalized information and knowledge integration platform for DL service”, Librarv Hi Tech, Vol.30, No.3, pp.490-512.

Kim, Y.-M., \& Abbas, J. (2010), “Adoption of library 2.0 functionalities by academic libraries and users: a knowledge management perspective", The Journal of Academic Librarianshin, Vol. 36 No. 3, pp. 211-218.

Kumar, P.S.G. (1987), Computerization of Indian libraries, New Delhi: B.R. Publishing Corporation.

Madhusudhan, M., \& Nagabhushanam, V. (2013), "Use of web-based library services in select university libraries in India: a study", International Journal of Library and Information Studies Vol.2 No.1, pp. 1-20.

Mavodza, J. \& Ngulube, P. (2011), "The use of technology-based mechanisms and knowledge management techniques in library practices in academic environment: A case study", Mousaion, Vol.29, No.2, pp.95-116.

Mohsenzadeh, F., \& Isfandyari-Moghaddam, A. (2008), “Application of information technologies in academic libraries", The Electronic Librarv, Vol. 27 No. 6, pp. 986-998.

Mphidi, H., \& Snyman, R. (2004), "The utilization of an intranet as a knowledge management tool in academic libraries", The Electronic Librarv, Vol. 22 No. 5, pp. 393-400.

National Knowledge Commission, Government of India. (2007), "Libraries: gateways to knowledge", available at: http://knowledgecommission.gov.in/downloads/documents/NKC_Library.pdf (accessed on 29 July 2014.

Nazim, M., \& Mukherjee, B. (2013), “Knowledge management competencies required among library and information science professionals: An Indian perspective", Librarv Review, Vol. 62 No. 6/7), pp. $375-387$

Nelson, E. (2008), "Knowledge management for libraries”, Library Administration \& Management, Vol.22, No.3, pp.135-137.

Okumus, F. (2012), "Facilitating knowledge management through information technology in hospitality organizations", Journal of Hospitality and Tourism Technologv, Vol. 4 No. 1, pp. 64-80.

Parirokh, M., Daneshgar, F., \& Fattahi, R. (2008), "Identifying knowledge sharing requirements in academic libraries". Librarv Review, Vol. 57 No. 2, pp.107-122.

Peyala, V. (2011), "Impact of using information technology in central university libraries in India" Results of a survey", Program: electronic library and information systems, Vol. 45 No. 3, pp. 308322.

Powell, R.R. \& Connaway, L.S. (2004), Basic research methods for librarians, London: Libraries Unlimited.

Preedip, B. B., \& Kumar, V. (2011), "Use of web technology in providing information services by south Indian technological universities as displayed on library websites", Librarv Hi Tech, Vol. 29 No. 3, pp. 470-495.

Rah, J. A., Gul, S., \& Wani, Z. A. (2010). University libraries: Step towards a web based knowledge management system. VINE: the iournal of information and knowledge management sustems, Vol. 40 No. 1, pp. 24-38.

Raman, P. V., \& Rao, V. C. (2003), "Use of information technology in central university libraries of India", DESIDOC Bulletin of Information Technologv, Vol. 23 No. 2, pp. 25-42. 
Raza, M.M., \& Nath, A. (2007), "Use of IT in university libraries of Punjab, Chandigarh and Himachal Pradesh: a comparative study", The International Information \& Librarv Review, Vol. 39, pp. 211-27.

Redden, C. S. (2010), "Social Bookmarking in Academic Libraries: Trends and Applications", The Journal of Academic Librarianship, Vol. 36, No. 3, pp. 219-227.

Ramzan, M., \& Singh, D. (2009), "Status of information technology applications in Pakistani libraries", Electronic Library, Vol. 27 No. 4, pp. 573-584.

Robertson, S., \& Sullivan, S. (2000), “The rediscovered agents of change: librarians working with academics to close the information gap". Paper presented at the Australian Library and Information Association on Capitalizing on Knowledge: The information profession in the 21st Century, October 23-26, 2000, Canberra, Australia. Retrieved April 13, 2014, from http://eric.ed.gov/PDFS/ED452877.pdf.

Sabashini, R., Rita, S., \& Vivek, M. (2012), "The role of ICTs in knowledge management for organizational effectiveness”, In: P.V. Krishna, M.R. Babu, and E. Ariwa (Eds.), Global Trends in Information Svstems and Software Applications (po.542-549), Springer-Verlag: Berlin Heidelberg.

Shanhong, T. (2000), "Knowledge management in libraries in the twenty first century", In World library and information congress: 66th IFLA council and general conference, August 13-18, 2000, Jerusalem.

Singh, S. P. (2007), “What are we managing: knowledge or information?' VINE: The Journal of Information \& Knowledge Management Systems, Vol. 37 No. 2, pp. 169-179.

Tiwari, B. K., \& Sahoo, K. C. (2013), "Infrastructure and Use of ICT in University Libraries of Rajasthan (India)", Library Philosophy and Practice, (e-journal), Paper 883, available at: http://digitalcommons.unl.edu/libphilprac/883 (accessed on 12 August 2014).

Stover, M. (2004), "Making tacit knowledge explicit: the ready reference database as codified knowledge", Reference Services Review, Vol. 32 No. 2, pp.164-173.

Tripathi, M., \& Kumar, S. (2010), "Use of Web 2.0 tools in academic libraries: a reconnaissance of the international landscape", The International Information \& Librarv Review, Vol. 42, pp. 195-207.

Tyagi, S. (2012), "Use of web 2.0 technology by library professionals: Study of selected engineering colleges in western Uttar Pradesh". DESIDOC Journal of Librarv \& Information Technologv. Vo. 32, pp. 439-445.

Vyas, S. D. (2003), “Application of Information Technology in University Libraries of Rajasthan: A Survey Report", Paper presented at first International Convention on Automation of Libraries in Education and Research Institutions (CALIBER), Feb. 13-15, 2003, Ahmedabad India, available at: http://ir.inflibnet.ac.in/bitstream/1944/191/2/03cali_22.pdf (accessed on 29 July 2014).

Woodward, J. A. (2009). Creating the customer-driven academic library. Chicago: American Library Association.

Xu, C., Ouyang, F., \& Chu, H. (2009), "The Academic Library Meets Web 2.0: Applications and Implications", The Journal of Academic Librarianship, Vol. 35, No. 4, pp.324-331.

Yuan, Y. C., Zhao, X., Liao, Q. \& Chi, C. (2013), "The use of different information and communication technologies to support knowledge sharing in organizations: From E-mail to Micro-Blogging", Journal of the Ameriacn Socieetv for Information Science and Technologv. Vo. 64 No. 8, pp.16591670. 


\section{Biographical Details:}

Dr Shabahat Husain is working as Dean, Faculty of Arts and Head, Department of Library \& Information Science (LIS), Aligarh Muslim University, Aligarh. He has more than 35 years of experience in teaching and library administration, and is member of various national level committees of UGC. He holds a PhD in LIS from Lucknow University, and MPhil in Information Technology from Loughborough University of Technology, England. Prior to his current assignments he has served Maulana Azad Library (Central Library of Aligarh Muslim University) as University Librarian during 2008-2012. He has also worked as Lecturer, in the Department of LIS, University of Maiduguri, Nigeria during 1980- 1983. His areas of specialisation are: Information retrieval techniques, information technology, design of front-end systems, library classification and library management.

Dr Mohammad Nazim is currently working as Assistant Librarian in the Faculty of Law, Banaras Hindu University, Varanasi, Uttar Pradesh, INDIA. He received Master of Library and Information Science degree from Aligarh Muslim University, Aligarh and submitted thesis for the award of PhD degree in the Department of Library \& Information Science, Banaras Hindu University. He is recipient of best paper awards for presenting papers in conferences of Indian Library Association (ILA) and Society for Information Science (SIS). He has contributed twenty five research articles in various reputed national and international journals. His research interests include e-learning, open access to scholarly communication and knowledge management 
Table 1: List of participating libraries $(\mathrm{N}=15)$

\begin{tabular}{|c|c|c|c|c|c|c|}
\hline \multirow{3}{*}{\begin{tabular}{l}
\multicolumn{1}{c}{ A } \\
Serial \\
Number
\end{tabular}} & \multirow{3}{*}{$\begin{array}{c}\text { B } \\
\text { Name of the University libraries }\end{array}$} & \multicolumn{2}{|c|}{$\mathrm{C}$} & \multirow{3}{*}{$\begin{array}{c}\text { D } \\
\text { Total } \\
\text { Collection }\end{array}$} & \multirow{2}{*}{\multicolumn{2}{|c|}{$\begin{array}{c}\text { E } \\
\text { Library Staff }\end{array}$}} \\
\hline & & \multicolumn{2}{|c|}{ Year of establishment } & & & \\
\hline & & University & Library & & $\underset{*}{\text { NPS }}$ & $\begin{array}{c}\text { NSW* } \\
*\end{array}$ \\
\hline 1 & $\begin{array}{l}\text { Aligarh Muslim University } \\
\text { (AMU), Aligarh }\end{array}$ & 1920 & 1960 & 1186139 & 121 & 100 \\
\hline 2 & $\begin{array}{l}\text { Allahabad University (ALU), } \\
\text { Allahabad }\end{array}$ & 1837 & 1913 & 653164 & 88 & 44 \\
\hline 3 & $\begin{array}{l}\text { Babasaheb Bhimrao Ambedkar } \\
\text { University (BBAU), Lucknow }\end{array}$ & 1996 & 1996 & 13000 & 9 & 7 \\
\hline 4 & $\begin{array}{l}\text { Banaras Hindu University (BHU), } \\
\text { Varanasi }\end{array}$ & 1916 & 1917 & 1061378 & 159 & 122 \\
\hline 5 & Guru Ghasidas University (GGS), & 1983 & 1984 & 110000 & 22 & 19 \\
\hline 6 & $\begin{array}{l}\text { Indira Gandhi National Open } \\
\text { University (IGNOU) New Delhi }\end{array}$ & 1985 & 1986 & 130000 & 17 & 17 \\
\hline 7 & $\begin{array}{l}\text { Jamia Millia Islamia University } \\
\text { (JMIU), New Delhi }\end{array}$ & 1920 & 1920 & 340000 & 59 & 50 \\
\hline 8 & $\begin{array}{l}\text { Jawaharlal Nehru University } \\
\text { (JNU), New Delhi }\end{array}$ & 1968 & 1969 & 560000 & 99 & 78 \\
\hline 9 & $\begin{array}{l}\text { Manipur University (MPU), } \\
\text { Imphal }\end{array}$ & 1980 & 1980 & 160000 & 25 & 18 \\
\hline 10 & $\begin{array}{l}\text { Maulana Azad National Urdu } \\
\text { University MANUU) Hyderabad }\end{array}$ & 1998 & 1998 & 32498 & 22 & 22 \\
\hline 11 & $\begin{array}{l}\text { Mizoram University (MU), } \\
\text { Mizoram }\end{array}$ & 2001 & 2001 & 87431 & 26 & 20 \\
\hline 12 & $\begin{array}{l}\text { North Eastern Hill University } \\
\text { (NEHU), Shillong }\end{array}$ & 1973 & 1973 & 250000 & 73 & 63 \\
\hline 13 & $\begin{array}{l}\text { Pondicherry University (PU), } \\
\text { Pondicherry }\end{array}$ & 1985 & 1986 & 251000 & 53 & 36 \\
\hline 14 & University of Delhi (UOD), Delhi & 1922 & 1922 & 1475729 & 416 & 126 \\
\hline 15 & $\begin{array}{l}\text { Visva Bharati (VB), Shanti } \\
\text { Niketan, West Bengal }\end{array}$ & 1921 & 1925 & 376511 & 42 & 28 \\
\hline & Total & & & & 1122 & 700 \\
\hline
\end{tabular}

$*=$ Number of Post Sanctioned. ${ }^{*} *=$ Number of Staff Working

Table 2: Library Functions/Activities Automated

\begin{tabular}{|c|l|c|c|}
\hline $\begin{array}{c}\text { Serial } \\
\text { Number }\end{array}$ & Library Functions/Activities & Yes & No \\
\hline 1 & Acquisition \& Budget & $15(75 \%)$ & $5(25 \%)$ \\
\hline 2 & Circulation Systems & $17(85 \%)$ & $3(15 \%)$ \\
\hline 3 & Serial control & $17(85 \%)$ & $3(85 \%)$ \\
\hline 4 & Library Catalogues (OPAC) & $20(100 \%)$ & $0(0 \%)$ \\
\hline 5 & Management Information & $9(45 \%)$ & $11(55 \%)$ \\
\hline 6 & Security System (RFID, etc.) & $4(20 \%)$ & $16(80 \% 0$ \\
\hline
\end{tabular}


Table 3: ICT-based Information Services

\begin{tabular}{|c|l|l|c|}
\hline $\begin{array}{c}\text { Serial } \\
\text { Number }\end{array}$ & Services & Frequency & \% \\
\hline 1 & $\begin{array}{l}\text { Access to in-house developed library databases/OPAC/Web } \\
\text { OPAC }\end{array}$ & 16 & 80.0 \\
\hline 2 & $\begin{array}{l}\text { Online tutorials on how to use the information } \\
\text { resources/services }\end{array}$ & 8 & 40.0 \\
\hline 3 & $\begin{array}{l}\text { Access to electronic resources, (e-books, e- journals, e- } \\
\text { databases, etc.). }\end{array}$ & 15 & 75.0 \\
\hline 4 & $\begin{array}{l}\text { Access to open access information sources through in-house } \\
\text { developed subject gateways/Web portals }\end{array}$ & 7 & 11 \\
\hline 5 & Web-based reference or other information services & 3 & 15.0 \\
\hline 6 & FAQ database & 2 & 10.0 \\
\hline 7 & $\begin{array}{l}\text { Automatic (electronic) mailing } \\
\text { alert system }\end{array}$ & \\
\hline
\end{tabular}

Table 4: ICT-based tools for sharing of knowledge

\begin{tabular}{|c|l|c|c|}
\hline $\begin{array}{c}\text { Serial } \\
\text { Number }\end{array}$ & ICT-based KM tools & Frequency & \% \\
\hline 1 & E-mail & 20 & 100 \\
\hline 2 & Phone calls/Teleconferencing & 20 & 100 \\
\hline 3 & Intranet & 16 & 10 \\
\hline 4 & Videoconferencing & 3 & 15 \\
\hline 5 & Data Mining/Resource Discovery Tools & 4 & 20 \\
\hline 6 & Institutional Repositories/Digital libraries & 13 & 65 \\
\hline 7 & Wikis & 7 & 35 \\
\hline 8 & RSS & 6 & 30 \\
\hline 9 & Blogs & 2 & 10 \\
\hline 10 & Social Networking sites & 5 & 25 \\
\hline 11 & Book marking & 2 & 10 \\
\hline
\end{tabular}

Table 5: Training required for handling ICT-based Information Management Systems \& services

\begin{tabular}{|c|l|l|l|}
\hline $\begin{array}{c}\text { Serial } \\
\text { Number }\end{array}$ & $\begin{array}{l}\text { ICT-Based Information/Knowledge } \\
\text { Management System }\end{array}$ & Need Training & $\begin{array}{l}\text { Trained Staff } \\
\text { Available }\end{array}$ \\
\hline 1 & Database creation \& management & $6(30 \%)$ & $14(70 \%)$ \\
\hline 2 & Content Management & $12(60 \%)$ & $8(40 \%)$ \\
\hline 3 & Metadata/e-resource management & $13(65 \%)$ & $7(35 \%)$ \\
\hline 4 & Web/portal development & $15(75 \%)$ & $5(20 \%)$ \\
\hline 5 & Hardware Maintenance & $14(70 \%)$ & $6(30 \%)$ \\
\hline 6 & Computer Programming & $17(85 \%)$ & $3(15 \%)$ \\
\hline
\end{tabular}


Table 6: Barriers related to the use of ICT in Academic Libraries

\begin{tabular}{|c|l|c|c|}
\hline $\begin{array}{c}\text { Serial } \\
\text { Number }\end{array}$ & Challenges in ICT Application & Rank & \% \\
\hline 1 & Lack of trained Staff in ICT & 1 & 85.0 \\
\hline 2 & Low level of ICT skills among library users & 2 & 75.0 \\
\hline 3 & Unawareness of potential benefits of ICT & 3 & 75.0 \\
\hline 4 & Lack of fund for ICT & 4 & 70.0 \\
\hline 5 & Inadequate ICT infrastructure & 5 & 55.0 \\
\hline 6 & Resistance of library staff to use ICT & 6 & 45.0 \\
\hline 7 & Lack of updated ICT policy or strategy & 7 & 35.0 \\
\hline
\end{tabular}




\section{APPENDIX}

\section{SECTION I}

1. Name of the University/Institute

2. Name of the Library

3. Year of Establishment:

(i) University/Institute

(ii) Library

4. Total Collection of the library

5. Website of your library

6. Name of the Librarian

7. Please mention the number of sectioned posts and number of employees are presently working in the library.

\begin{tabular}{|l|l|l|}
\hline Name of the post & $\begin{array}{l}\text { Number of } \\
\text { Sanctioned Post }\end{array}$ & $\begin{array}{l}\text { Number of Staff } \\
\text { Working }\end{array}$ \\
\hline University Librarian & & \\
\hline Deputy librarians & & \\
\hline Assistant Librarians & & \\
\hline Information Scientists & & \\
\hline Professional Assistants & & \\
\hline Semi-Professional Assistants & & \\
\hline Technical Assistants & & \\
\hline Other (please specify) & & \\
\hline Total & & \\
\hline
\end{tabular}

\section{SECTION II}

1. Which of the following functions/activities are computerized in your library? (Please select all that apply)

\begin{tabular}{|l|l|}
\hline Acquisitions \& budgets & \\
\hline Circulation control & \\
\hline Serial control & \\
\hline Management information & \\
\hline Library catalogue (Online Public Access Catalogue) & \\
\hline Security system (i.e. RFID): & \\
\hline Other (please specify) & \\
\hline
\end{tabular}

2. Which of the following ICT-based Information Services does your library provide to the users? (Please select all that apply)

Access to in-house developed library databases/OPAC/Web OPAC

Online tutorials on how to use the information resources/services

Access to electronic resources, (e-books, e- journals, e-databases, etc.).

Access to open access information sources through in-house developed subject gateways/Web portals

Web-based reference or other information services

FAQ database

Automatic (electronic) mailing alert system

Other (please specify) 


\section{SECTION III}

Which of the following ICT-based interactive communication tools are used in your library for sharing of knowledge? (Please select all that apply)

\begin{tabular}{|l|l|}
\hline E-mail & \\
\hline Phone calls/Teleconferencing & \\
\hline Intranet & \\
\hline Videoconferencing & \\
\hline Institutional Repositories/Digital libraries & \\
\hline Data Mining/Resource Discovery Tools & \\
\hline Wikis & \\
\hline RSS & \\
\hline Blogs & \\
\hline Social Networking sites & \\
\hline Book marking & \\
\hline Other (please specify) & \\
\hline
\end{tabular}

\section{SECTION IV}

Which of the following ICT-based information management systems are staffed by qualified personnel in your library? If adequate staffing or skill is lacking in an area, indicate if training is needed.

\begin{tabular}{|l|l|l|}
\hline & $\begin{array}{l}\text { Trained Staff } \\
\text { Available }\end{array}$ & Need Training \\
\hline Hardware Maintenance & & \\
\hline Computer Programming & & \\
\hline Database creation \& management & & \\
\hline Content Management & & \\
\hline Metadata/e-resource management & & \\
\hline Web/portal development & & \\
\hline Other (please specify) & & \\
\hline
\end{tabular}

\section{SECTION V}

What are the constraints do you face in the use of ICT in your Library? Please rate 1 to 7 in order of priority.

Inadequate ICT infrastructure

Lack of fund for ICT

Unawareness of potential benefits of ICT

Lack of trained Staff in ICT

Low level of ICT skills among library users

Resistance of library staff to use ICT

Lack of updated ICT policy or strategy

Other (please specify) 